\title{
Proposed Marketing Strategy for Freight Services Based on Consumer Preferences and Perceptions with the Multidimensional Scaling Method
}

\author{
Misra Hartati*, Delfi Mairoza, Dewi Diniaty, Silvia, Muhammad Ihsan Hamdy \\ Jurusan Teknik Industri, Fakultas Sains dan Teknologi, Universitas Islam Negeri Sultan Syarif Kasim Riau \\ Jl. HR. Soebrantas No. 155 Simpang Baru, Panam, Pekanbaru, 28293, Indonesia \\ Email:misrahartati@uin-suska.ac.id, delfimairoza@gmail.com,dewidiniaty@uin-suska.ac.id \\ silvia@uin-suska.ac.id, m.ihsanhamdy@uin-suska.ac.id
}

\section{ABSTRACT}

This research is one of the freight forwarding companies in Indonesia to various regions or cities. However, the presence of many freight forwarding companies has caused many competitors to make it less a priority for SMEs to deliver goods. The purpose of this study is to design a marketing strategy for freight forwarding services based on consumer preferences and perceptions. The method used in this research is Multidimensional Scaling. This method is one procedure for classifying consumer preferences and perceptions based on visual similarities in a geometry. The results of this study are in the form of a proposed marketing strategy for freight forwarding services based on the 7P (Marketing Mix) mix concept.

Keyword: Marketing Mix, Multidimensional Scaling, Perception, Perceptual Map, Preferences, Proposed Marketing Strategies.

\section{Preliminary}

Nowadays, the service sector develops highly advanced. Many companies offer services to consumers for certain needs. One of them is freight forwarding services. The services are a business field that is very much in demand by people who want to start a business. The most influential factor of the development of shipping services is the increasing number of wholesale stores that provide online purchases to meet the needs of consumers from various regions.

As the more wholesale stores provide online purchases, thus SME actors are increasingly selective in choosing a freight service that can deliver products quickly, but the condition of the goods remains safe because of the wide range of areas where goods will be sent and the number of requests for delivery to various areas.

PT. $X$ is one of the freights forwarding companies in Indonesia that provide services for shipping goods to various regions or cities. However, the growing needs of consumer goods shipping services cause many competitors in shipping services. The sales data from PT. X from September to November 2019 are:

Table 1 Shipping Data of PT. X

\begin{tabular}{lccc}
\hline No & Month & Week & $\begin{array}{c}\text { Weight } \\
\text { (ton/week) }\end{array}$ \\
\hline \multirow{3}{*}{1} & \multirow{2}{*}{ September } & 1 & 6 \\
\cline { 3 - 4 } & & 2 & 3.5 \\
\cline { 3 - 4 } & & 3 & 4.7 \\
\cline { 2 - 3 } & & 4 & 5.8 \\
\hline
\end{tabular}

\begin{tabular}{|c|c|c|c|}
\hline & Total & & 20 \\
\hline \multirow{4}{*}{2} & \multirow{4}{*}{ October } & 1 & 8 \\
\hline & & 2 & 4.37 \\
\hline & & 3 & 5 \\
\hline & & 4 & 4.63 \\
\hline & Total & & 22 \\
\hline \multirow{5}{*}{3} & \multirow{4}{*}{ November } & 1 & 5 \\
\hline & & 2 & 5 \\
\hline & & 3 & 3.75 \\
\hline & & 4 & 6.25 \\
\hline & Total & & 20 \\
\hline
\end{tabular}

Based on the data above, the branch company did not reach the target given by the central company. According to Rangkuty (2002), The target given is very influential in all finances of the branch office. The central company is not responsible for the finances of the branch office. As for the reasons, for the lack of achievement of the target, the company is less of a priority for wholesale centers in choosing freight forwarding services and because of many competitors sending services that have advantages that make customers more interested.

According to Nahar (2006) and Andriani (2019), The need of marketing strategy proposals based on consumer preferences and perceptions using Multidimensional Scaling and marketing mix. Multidimensional scaling is useful for mapping or classifying consumer preferences and perceptions based on visual similarity (Malhotra, 2010). While the marketing mix (marketing mix) is to design marketingstrategies based on the strengths and weaknesses of PT. X with competing companies. 
The company needs to identify consumers, the most important attributes for consumers, the closest competitors and the most influential factors and expected that the company can again become the people's first choice in freight forwarding services.

\section{Research Methods}

Sampling design

The sampling technique of this study was purposive sampling. Researchers used certain considerations in selecting population members as a sample. The sample units are linked according to established criteria based on the research objectives. The minimum number of samples were 100 people given a questionnaire. The respondents of this study were consumers who were SME actors.

Data collection technique

Data collection techniques used in this study were:

a. Communication technique

It is used for a primary data collection using a questionnaire distributed to respondents directly. The questionnaire was about the importance of preference level, ranking preference, and perception.

b. Observation technique

it is used for secondary data collection such as company profiles and data from the company.

c. Questionnaire scale

The scores given for each answer in the questionnaire are:

$1=$ Not at all important

$2=$ Slightly Important

$3=$ Hesitant

$4=$ Important

$5=$ Very Important

Data processing technique

Data processing techniques of this study were:

a. Validity and reliability testing

The research administered the data to examine the validity and reliability. This step required to determine if the data is valid and reliable. If the data is invalid and not reliable, it is necessary to redistribute questionnaires. If $\mathrm{r}_{\text {count }} \geq \mathrm{rt}_{\mathrm{able}}$, the data is valid. If the data is not valid, then the questions on the questionnaire must be replaced or eliminate variables.

b. The Multidimensional Scaling Method used SPSS 23 Software. To calculate the ranking data using the Multidimensional Scaling method in SPSS 23. The steps of this method are:

1) Determine data by distributing questionnaires to respondents.

2) Recap the results of the questionnaire in the form of a table.
3) Map the attribute of interest data in the form of a perceptual mapping map using SPSS 23 software. SPSS 23 software steps are:

a) Input data in the SPSS worksheet.

b) Choose analyze - scale - multidimensional scaling.

c) A multidimensional Scaling box appears, enter all variables, select rectangular shapes then click continue.

d) After the Multidimensional Scaling: Model dialog box appears, then select the Level of Measure Interval box and select the row in the conditional box, then click continue.

e) After the first dialog box comes out then click options and select group plots then click OK.

f) Out the results of the multidimensional scaling output.

4) Calculate the proximity of the object using the formula.

This data is processed by the Multidimensional Scaling method using SPSS 23 software with the following steps:

a) Recap the results of respondents' answers from questionnaires. Then determine the number and average of the results of the respondent's answers.

b) Determine the matrix data using an average of the results of the respondent's answer summary.

c) Input matrix data to SPSS to form perceptual maps.

d) Select analyse - scale - multidimensional scaling.

e) Next on the data format mark the data are proximities and on the number of

f) sources mark one matrix source then click define.

g) Move all variables to proximities, then click output.

h) Then mark the common space coordinate, distance, and multiple stress measures then click continues.

i) The results of multidimensional scaling processing will come out.

j) The nearest competitor compared with PT. X will take the results of consumer perception based on the attributes chosen by consumers and the $7 \mathrm{P}$ marketing mix concept as a marketing strategy proposal.

\section{Results and Discussion}

Testing of Measuring Instruments

Testing of measuring instruments was conducted by validity and reliability tests. The data used results from the importance level questionnaire 
distributed to 100 respondents. Following are the importance level questionnaire data:

Tabel 2. Importance level questionnaire data

\begin{tabular}{|c|c|c|c|c|c|c|c|c|c|c|c|c|c|c|c|c|c|}
\hline \multirow{2}{*}{ Responden } & \multicolumn{16}{|c|}{ Atribut } & \multirow{2}{*}{ Jumlah } \\
\hline & 1 & 2 & 3 & 4 & 5 & 6 & 7 & 8 & 9 & 10 & 11 & 12 & 13 & 14 & 15 & 16 & \\
\hline 1 & 5 & 4 & 4 & 3 & 4 & 3 & 3 & 4 & 3 & 4 & 3 & 4 & 4 & 4 & 5 & 5 & 62 \\
\hline 2 & 4 & 4 & 4 & 3 & 4 & 3 & 4 & 3 & 4 & 2 & 2 & 4 & 4 & 3 & 5 & 4 & 57 \\
\hline 3 & 5 & 4 & 4 & 4 & 4 & 3 & 4 & 4 & 2 & 2 & 2 & 4 & 4 & 3 & 5 & 5 & 59 \\
\hline 4 & 4 & 4 & 4 & 4 & 4 & 2 & 4 & 4 & 2 & 2 & 3 & 3 & 3 & 3 & 4 & 4 & 54 \\
\hline 5 & 5 & 5 & 5 & 3 & 4 & 3 & 3 & 4 & 3 & 3 & 3 & 5 & 5 & 3 & 4 & 4 & 62 \\
\hline 6 & 4 & 4 & 5 & 3 & 4 & 3 & 4 & 4 & 3 & 3 & 4 & 4 & 4 & 4 & 4 & 4 & 61 \\
\hline 7 & 5 & 4 & 3 & 4 & 4 & 3 & 3 & 4 & 4 & 4 & 5 & 5 & 5 & 5 & 5 & 5 & 68 \\
\hline 8 & 5 & 4 & 4 & 4 & 5 & 3 & 4 & 4 & 3 & 3 & 3 & 4 & 4 & 4 & 4 & 4 & 62 \\
\hline 9 & 4 & 4 & 4 & 5 & 4 & 4 & 3 & 3 & 4 & 4 & 4 & 4 & 4 & 5 & 4 & 4 & 64 \\
\hline 10 & 5 & 5 & 5 & 4 & 4 & 4 & 4 & 4 & 4 & 3 & 3 & 4 & 5 & 4 & 4 & 5 & 67 \\
\hline .. & .. & .. & .. & .. & .. & .. & .. & .. & .. & .. & .. & .. & .. & .. & .. & .. & .. \\
\hline 95 & 5 & 5 & 4 & 4 & 5 & 3 & 3 & 3 & 2 & 4 & 3 & 4 & 4 & 4 & 5 & 5 & 63 \\
\hline 96 & 5 & 5 & 5 & 5 & 5 & 5 & 4 & 5 & 5 & 5 & 4 & 5 & 5 & 5 & 5 & 5 & 78 \\
\hline 97 & 5 & 5 & 5 & 5 & 5 & 5 & 4 & 4 & 4 & 4 & 5 & 4 & 4 & 4 & 4 & 4 & 71 \\
\hline 98 & 4 & 4 & 4 & 5 & 5 & 5 & 4 & 5 & 5 & 4 & 4 & 5 & 4 & 4 & 5 & 5 & 72 \\
\hline 99 & 5 & 5 & 5 & 5 & 5 & 4 & 4 & 4 & 5 & 4 & 5 & 5 & 4 & 5 & 5 & 5 & 75 \\
\hline 100 & 5 & 4 & 5 & 5 & 5 & 4 & 4 & 3 & 4 & 4 & 3 & 5 & 5 & 4 & 5 & 5 & 70 \\
\hline
\end{tabular}

Based on the data in table 2. The validity test results are as follows:

Table 3. Test Validity

\begin{tabular}{clccc}
\hline No & \multicolumn{1}{c}{ Attribute } & $\mathbf{R}_{\text {count }}$ & $\mathbf{R}_{\text {table }}$ & Note \\
\hline 1 & Punctuality & 0.611 & 0.1966 & Valid \\
\hline 2 & Precise of goods delivery & 0.610 & 0.1966 & Valid \\
\hline 3 & Delivery speed & 0.498 & 0.1966 & Valid \\
\hline 4 & Handling goods & 0.689 & 0.1966 & Valid \\
\hline 5 & Security of goods & 0.656 & 0.1966 & Valid \\
\hline 6 & Service variations & 0.639 & 0.1966 & Valid \\
\hline 7 & Price variations & 0.529 & 0.1966 & Valid \\
\hline 8 & Payment method & 0.609 & 0.1966 & Valid \\
\hline 9 & Advertisement & 0.560 & 0.1966 & Valid \\
\hline 10 & Location strategies & 0.741 & 0.1966 & Valid \\
\hline 11 & Employee appearance & 0.602 & 0.1966 & Valid \\
\hline & The ability of employees to & & & \\
12 & provide information & 0.704 & 0.1966 & Valid \\
\hline 13 & Employee friendliness & 0.537 & 0.1966 & Valid \\
\hline
\end{tabular}

The results of the reliability test were:

Table 4. Reliability tests

\begin{tabular}{lcc}
\hline \multicolumn{1}{c}{ Atribut } & $\begin{array}{c}\text { Cronbach's } \\
\text { Alpha }\end{array}$ & N of items \\
\hline $\begin{array}{l}\text { Tingkat } \\
\text { Kepentingan }\end{array}$ & 0,893 & 16 \\
\hline
\end{tabular}


Based on table 4 above, the measurement tool can be accepted based on the value of Cronbach's alpha.

\section{Multidimensional Scaling Method}

There are data of the importance level, ranking preference, and perception. Following is the data processing using multidimensional scaling method: a. Preference of the importance level

It aims to find out the attributes considered important by consumers in choosing a shipping service. The following is the recapitulation of importance level preferences:

Table 5. Preference of importance

\begin{tabular}{cllccc}
\hline No & $\begin{array}{c}\text { Marketing } \\
\text { Mix }\end{array}$ & \multicolumn{1}{c}{ Atribut } & Inisiasi & Jumlah & $\begin{array}{c}\text { Rata- } \\
\text { rata }\end{array}$ \\
\hline 1 & Product & Delivery speed & X1 & 427 & 4,27 \\
\hline 2 & Product & Security of goods & X5 & 424 & 4,24 \\
\hline 3 & People & Employee friendliness & X13 & 421 & 4,21 \\
\hline 4 & Process & Punctuality & X16 & 420 & 4,2 \\
\hline 5 & Product & Precise of goods delivery & X2 & 419 & 4,19 \\
\hline 6 & Product & Delivery speed & X3 & 417 & 4,17 \\
\hline 7 & Product & Handling goods & X4 & 403 & 4,03 \\
\hline 8 & Process & Monitoring goods & X15 & 388 & 3,88 \\
\hline 9 & Price & Payment method & X8 & 386 & 3,86 \\
\hline 10 & People & The ability of employee to provide & 382 & 3,82 \\
\hline 11 & Phsycal & Ease of transactions & X14 & 372 & 3,72 \\
\hline 12 & Product & Service variation & X6 & 368 & 3,68 \\
\hline 13 & Price & Price variation & X10 & 358 & 3,58 \\
\hline 14 & Place & Location strategies & X9 & 339 & 3,49 \\
\hline 15 & Promotion & Advertisement & X11 & 339 & 3,39 \\
\hline 16 & People & Employee appearance & & 3,39 \\
\hline
\end{tabular}

Table 5. shows the order of attributes considered important by consumers in choosing goods shipping services. This is based on an average of each attribute of the freight forwarding service.

b. Ranking Preference

Ranking preference was conducted to determine the comparison of PT. X with competing companies. The following are ranking preference data.

Tabel 6. Preference of atribut level 1

\begin{tabular}{ccccc}
\hline \multirow{2}{*}{ Responden } & \multicolumn{4}{c}{ Atribut 1} \\
\cline { 2 - 5 } & $\mathrm{X}$ & $\mathrm{X} 1$ & $\mathrm{X} 2$ & $\mathrm{X} 3$ \\
\hline 1 & 1 & 3 & 5 & 4 \\
\hline 2 & 4 & 2 & 3 & 5 \\
\hline 3 & 1 & 3 & 5 & 4 \\
\hline
\end{tabular}

\begin{tabular}{ccccc}
\hline 4 & 2 & 3 & 5 & 4 \\
\hline 5 & 3 & 2 & 4 & 5 \\
\hline.. &.. &.. &.. &.$\cdot$ \\
\hline 96 & 3 & 4 & 5 & 1 \\
\hline 97 & 5 & 1 & 2 & 3 \\
\hline 98 & 1 & 2 & 3 & 4 \\
\hline 99 & 2 & 3 & 4 & 5 \\
\hline 100 & 1 & 2 & 3 & 4 \\
\hline
\end{tabular}

The table above shows the results of the rangking preferences for attribute 1 . The following are the results of the rangking preferences of attributes 1 to 16 
Table 7. Preference of importance

\begin{tabular}{|c|c|c|c|c|c|c|c|}
\hline \multirow{2}{*}{ No } & \multirow{2}{*}{ Attribute } & \multirow{2}{*}{$\begin{array}{l}\text { Attribute } \\
\text { Initiation }\end{array}$} & \multicolumn{4}{|c|}{ Company Name } & \multirow{2}{*}{ Row } \\
\hline & & & $\mathrm{X}$ & $\mathrm{X} 1$ & $\mathrm{X} 2$ & $\mathrm{X} 3$ & \\
\hline 1 & Punctuality & $\mathrm{X} 1$ & 2.1 & 2.63 & 3.51 & 3.97 & Row 1 \\
\hline 2 & Precise of goods delivery & $\mathrm{X} 2$ & 3.8 & 2.86 & 3.61 & 2.4 & Row 2 \\
\hline 3 & Delivery speed & $\mathrm{X} 3$ & 2.55 & 2.67 & 3.77 & 3.98 & Row 3 \\
\hline 4 & Handling goods & $\mathrm{X} 4$ & 3.81 & 2.69 & 3.76 & 2.4 & Row 4 \\
\hline 5 & Security of goods & $\mathrm{X} 5$ & 2.23 & 2.73 & 3.73 & 4.13 & Row 5 \\
\hline 6 & Service variation & $\mathrm{X6}$ & 1.92 & 2.6 & 3.52 & 4.09 & Row 6 \\
\hline 7 & Price variation & $\mathrm{X} 7$ & 3.97 & 2.64 & 3.57 & 1.9 & Row 7 \\
\hline 8 & Payment method & $\mathrm{X} 8$ & 2.16 & 2.79 & 3.9 & 3.85 & Row 8 \\
\hline 9 & Advertisement & X9 & 1.85 & 2.4 & 3.58 & 4.14 & Row 9 \\
\hline 10 & Location strategies & $\mathrm{X} 10$ & 2.23 & 2.74 & 3.76 & 3.83 & Row 10 \\
\hline 11 & Employee appearance & $\mathrm{X} 11$ & 2.15 & 2.59 & 3.53 & 4.03 & Row 11 \\
\hline 12 & $\begin{array}{l}\text { The ability of employee to } \\
\text { provide information }\end{array}$ & $\mathrm{X} 12$ & 3.97 & 2.63 & 3.79 & 2.58 & Row 12 \\
\hline 13 & Employee friendliness & $\mathrm{X} 13$ & 3.91 & 2.68 & 3.72 & 2.42 & Row 13 \\
\hline 14 & $\begin{array}{l}\text { Convenience of transaction } \\
\text { place }\end{array}$ & $\mathrm{X} 14$ & 2.05 & 2.76 & 3.46 & 3.89 & Row 14 \\
\hline 15 & Monitoring goods & $\mathrm{X} 15$ & 2.23 & 2.77 & 3.83 & 4.01 & Row 15 \\
\hline 16 & Ease of transactions & $\mathrm{X} 16$ & 2.37 & 2.69 & 3.73 & 3.94 & $\operatorname{Rox} 16$ \\
\hline
\end{tabular}

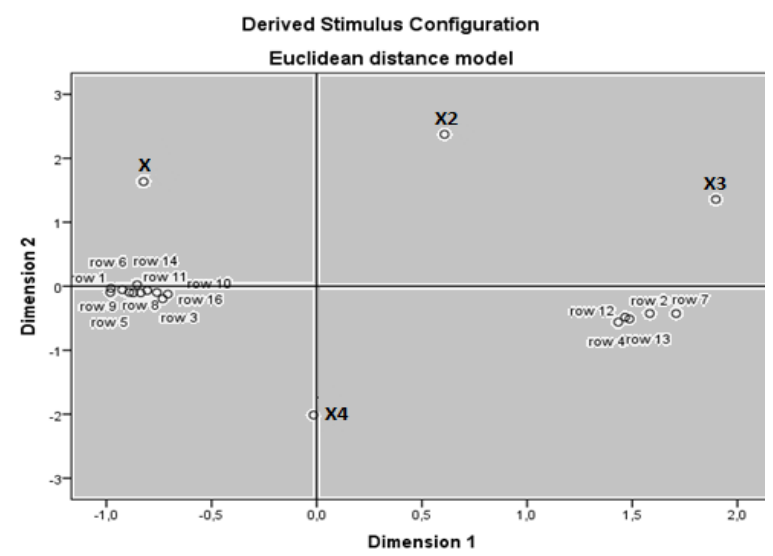

\section{c. Perception}

Perceived data processing aims to determine the value of closeness between PT.X with competitors. The following are the results of the perception questionnaire:

Table 8. Results of perception questionnaire:

No Company Name Total Mean

\begin{tabular}{llll} 
No & Company Name & Total & Mean \\
\hline 1 & X vs X1 & 335 & 3.35 \\
2 & X vs X2 & 321 & 3.21 \\
3 & X vs X3 & 298 & 2.98 \\
4 & X1 vs X2 & 369 & 3.69 \\
5 & X1 vs X3 & 364 & 3.64 \\
6 & X2 vs X3 & 392 & 3.92 \\
\hline
\end{tabular}

Figure 1. Ranking preference results ception

The average obtained in Table 6 was used as a matrix which was the input for processing perception data using Multidimensional Scaling with the help of SPSS 23 Software.

Table 9. Matrix of perception data

\begin{tabular}{ccccc}
\hline Company Name & $\mathrm{X}$ & $\mathrm{X} 1$ & $\mathrm{X} 2$ & $\mathrm{X} 3$ \\
\hline $\mathrm{X}$ & 0 & 3.35 & 3.21 & 2.98 \\
\hline $\mathrm{X} 1$ & 3.35 & 0 & 3.69 & 3.64 \\
\hline $\mathrm{X} 2$ & 3.21 & 3.69 & 0 & 3.92 \\
\hline $\mathrm{X} 3$ & 2.98 & 3.64 & 3.92 & 0 \\
\hline
\end{tabular}

Data processing resulted the distance between shipping services and illustrated on the perceptual map. Based on the perception data matrix, it was obtained the result of the distance of goods delivery services between $\mathrm{X}, \mathrm{X} 1, \mathrm{X} 2$ and $\mathrm{X} 3$.
From the results of these distances it was known that the closest X distance to X3.

Result of the distance of good delivery shouw on the table 10 . 
Table 10. Result of the distance of good deliver

\begin{tabular}{crrrr}
\hline Nama Perusahaan & X & X1 & X2 & X3 \\
\hline X &, 000 & & & \\
\hline X1 & 1,083 &, 000 & & \\
\hline X2 &, 780 &, 984 &, 000 & \\
\hline X3 &, 714 &, 964 & 1,307 &, 000 \\
\hline
\end{tabular}

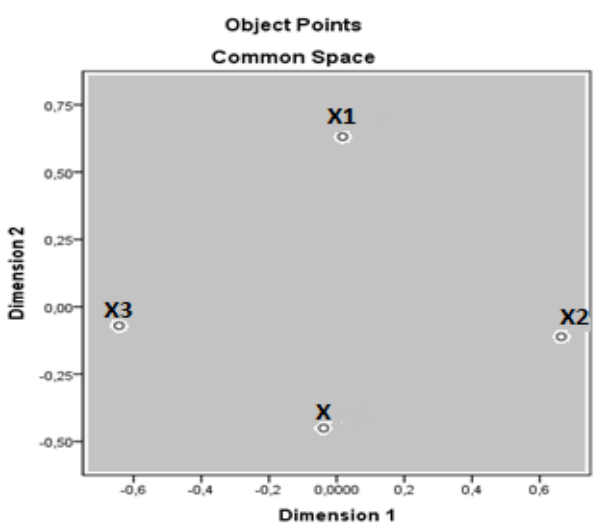

Proposed Service Marketing Strategy Based on Mix 7P.

Companies also have to know the superior attributes to compete with competitors. Excellent attributes should be identified and maintained. In contrast, the inferior attributes also need to be recognized and maximized to compete with other companies. Leading attributes were from the distribution of ranking preference questionnaires. Following are the superior attributes of $\mathrm{X}$ and $\mathrm{X} 3$ :

Figure 2 results of perception

Table 11. Leading attributes

\begin{tabular}{lll}
\hline \multirow{2}{*}{ Company } & \multicolumn{1}{c}{ Excellent Attributes } & \multicolumn{1}{c}{$\begin{array}{c}\text { Attributes } \\
\text { Initiation }\end{array}$} \\
\hline \multirow{3}{*}{$\mathrm{X}$} & Precise of goods delivery & $\mathrm{X} 2$ \\
\cline { 2 - 3 } & Handling goods & $\mathrm{X} 4$ \\
\cline { 2 - 3 } & Price variation & $\mathrm{X} 7$ \\
\cline { 2 - 3 } & Employee Friendliness & $\mathrm{X} 13$ \\
\cline { 2 - 3 } & The ability of employee to provide information & $\mathrm{X} 12$ \\
\hline \multirow{3}{*}{ Punctuality } & $\mathrm{X} 1$ \\
\cline { 2 - 3 } & Delivery speed & $\mathrm{X} 3$ \\
\cline { 2 - 3 } & Security of goods & $\mathrm{X} 5$ \\
\cline { 2 - 3 } & Services variation & $\mathrm{X} 6$ \\
\cline { 2 - 3 } & Payment method & $\mathrm{X} 8$ \\
\cline { 2 - 3 } & Advertisement & $\mathrm{X} 9$ \\
\cline { 2 - 3 } & Location strategies & $\mathrm{X} 10$ \\
\cline { 2 - 3 } & Employee appearance & $\mathrm{X} 11$ \\
\cline { 2 - 3 } & Convenience of transaction place & $\mathrm{X} 14$ \\
\cline { 2 - 3 } & Monitoring goods & $\mathrm{X} 16$ \\
\cline { 2 - 3 } & Ease of transaction & \\
\cline { 2 - 3 } & &
\end{tabular}

The proposed marketing strategy based on the superior attributes listed in Table 9 using the 7P Marketing Mix. This proposal was based on the perceptions and preferences of consumers who used goods shipping services.

1. Product

a. The company cooperates with transposition companies so that shipments do not pile up. b. Maintaining superior attributes by recruiting employees who have regional insight according to the branch office

c. Providing fast and precise services according to the wishes of consumers so that consumers can return to using the same shipping service. 
d. Pay attention to the safety of the goods by adding additional wrapping or cardboard to maintain the quality of the goods.

e. Give a warning to employees who do not work well.

f. Keeping goods in the hands of consumers will also be an add value for the company so that consumers return to using the shipping service

g. Increasing the variety of services so that consumers have more options to choose the services.

2. Price

a. Maintain prices with quality handling and safety that must be considered.

b. Providing online payment accounts for consumers and providing official social media to show proof of payment when consumers make payments online.

3. Promotion

a. Introduce services to the community by participating in events appropriate to the business.

b. Routine promotions were conducted regularly that is interesting so that consumers don't get bored.

c. Promotion is executed by word of mouth method.

d. Providing discounts for customers who send packages in enormous quantities.

1. Place

a. Consider the right location to get customers according to the shipping target.

b. Open a branch by choosing a place that has a lot of consumers such as shopping places.

2. People

a. The owner must always monitor the performance of employees and the company.

b. Employees who provide more value to the company can be rewarded.

c. Building a good interaction between employees.

d. Companies need to raise standards based on the training provided so they can do their jobs well and readily so they can serve consumers quickly.

e. Considering the opinions of consumers towards the company because consumers are the most important parties the company can stand.

f. Give an employee an identity so that consumers can know that person is an employee

3. Physical Evidence

a. The convenience of the place of service need to be considered with the regeneration of facilities that are not workable

b. Building design should update to reduce the level of saturation of employees and consumers who come.

4. Process

a. Provides tracking of goods so consumers can find out where their goods are.

b. Make an easily accessed website on mobile phones.

c. Reducing delays in consumer complaints by providing direct evidence to consumers.

\section{Conclusion}

This research concludes the proposed marketing strategy is designed by using 7P (Marketing Mix) based on consumer preferences and perceptions. The suggestions of this research are:

1. The company can implement the proposed marketing strategy in this research to increase consumer interest in choosing a shipping service $\mathrm{X}$ in shipping goods.

2. The other researches can add supporting methods for example Electre Method which is useful as a decision support system on the marketing mix. This is profitable for the perfection of research in subsequent studies.

\section{Reference}

Adriani, S,. dkk (2018). Analysis of Consumers Perception at the Food Court of Lampung Walk by Using Multidimensional Scaling Approach. Mathematical Education Journal 2(9), 2092019.

Fandy .T. (2014). Pemasaran Jasa. Yogyakarta: CV.Andi Offset.

Harahap, E, F,. (2018). Pengaruh Strategi Pemasaran terhadap Keputusan Pembelian Asuransi Kendaraan Bermotor pada PT Asuransi Sinarmas Cabang Garut. Jounal of Knowledge Management . Vol. 12, No.1, pp 012-020.

Malhotra. K. N. (2010). Riset Pemasaran Pendekata Terapan. Jakarta: PT Indeks.

Nahar, J. (2016). Penerapan Metode Multidimensional Scaling dalam Pemetaan Sarana Kesehatan di Jawa Barat. Jurnal Matematika Integratif. Vol.12, No.1, pp. 43-50.

Naresh K. Malhotra (2010). Riset Pemasaran Pendekata Terapan. Jakarta: PT Indeks.

Rangkuty, F. (2002). Creating Effective Marketing Plan. Jakarta: PT. Gramedia Pustaka Utama 